\title{
Solidarity Practices in Poland and Their Social Capital Foundations
}

\author{
Anna Kurowska and Maria Theiss
}

\section{INTRODUCTION}

Poland is a country where the idea of solidarity is primarily associated with the "Solidarity" social movement which had a substantial influence on political change and democratization (Krzemiński 2010; Staniszkis 2010). However, while "Solidarity" as a movement and as a value was very important in the times of the fall of the communist system, the subsequent transformation period is often perceived as a "defeat of Solidarity" (Ost 2006), both in the institutional and attitudinal dimensions of public life. A significant literature points to low levels of social solidarity in Poland which is often linked to a relatively weak civic tradition and faint social capital, in particular trust (Giza et al. 2000; Czapiński 2006; Gliński 2006; Szymczak 2008).

The mentioned bulk of literature and its findings refer to the societal and, foremostly, the civic aspect of social transformation in Poland shortly after the fall of communism. However, contemporary political and economic changes both in Poland and other EU countries call for newer insights into the problems of solidarity in Poland. The economic crisis of

\footnotetext{
A. Kurowska $\bullet$ M. Theiss $(\bowtie)$

Institute of Social Policy, University of Warsaw, Warsaw, Poland

(C) The Author(s) 2018

C. Lahusen, M. Grasso (eds.), Solidarity in Europe, Palgrave Studies in European Political Sociology, https://doi.org/10.1007/978-3-319-73335-7_5
} 
2008, the influx of refugees to Southern European countries and the relocation policy of the EU, as well as political changes in Poland create a new context for solidarity attitudes and practices. Moreover, the conservative government of Law and Justice, which has been governing since 2015, manifestly uses the rhetoric of solidarity limited exclusively to Polish compatriots, combined with little charity for people suffering in conflicts abroad. As Bartkowski (2014) shows, although deterioration of international solidarity and rise of political egocentric attitudes are Europe-wide, they manifest in Poland intensively. His study provides evidence that solidarity within close family ties and within national polity has recently strengthened in Poland, on the contrary to transnational solidarity. Thus, both Polish specificity which encompasses traditionally low level of social trust (Domański 2009: 142-175), relatively weak social capital measured by density of civil society organizations and associations, and recent political narratives pose significant tensions to solidarity nowadays. This refers in particular to transnational solidarity - the solidarity action with people living abroad.

In this chapter, adding to the literature on political solidarity (rather than to the dominant discussion on social solidarity within institutions of welfare state), we make an insight into three types of solidarity practices and we investigate their geographical scope. We show the frequency of protesting, donating time and donating money in order to support the rights of the three different groups of addressees: the compatriots, the people in other EU member states and the people in countries outside the EU. We look at these aspects with the lens of three basic socio-demographic characteristics: gender, age and education. Further, we also make an analytical insight into the area of relations between individuals' social capital in Poland and these solidarity practices. Since Poland has been portrayed in scholarly literature as a country of low "civic" social capital and of strong familialistic bonds (Guasti 2016; Jakubowska and Kaniasty 2014; Czapiński 2014), as well as a country focused on in-group solidarity (Gliński 2006), we pose a question whether this specific post-communist legacy of social capital affects solidarity practices of Poles. In particular, we explore the role of bonding and bridging social capital in shaping solidarity behaviors in general, specifically its impact on transnational solidarity action.

In the first section of this chapter, we present understanding of solidarity as individuals' practice and discuss its linkages to the types of social capital in the context of a post-communist country. In the second section, the 
operationalization of transnational solidarity and social capital is presented. The third section of the chapter provides the overview of solidarity practices in its mentioned forms, toward three basic groups of addressees. In the fourth section, we present results of the logistic regression analysis with the use of which we aim to explain how generalized and transnational solidarity are related to diverse aspects of social capital. We conclude in the last section of the chapter emphasizing specific constellations of bonding and bridging social capital which contribute to solidarity practices in Poland.

\section{Structural and Normative Sources of Solidarity Action: The Case of a Post-Communist Country}

Despite the variety of meanings attributed to solidarity-of moral value, societal ideal, individual attitude or collective behavior-researchers tend to agree that its core understanding refers to the type of action. For example, Kolers (2012) notices that solidarity is fundamentally neither sentiment nor attitude but a type of action which is associative and teleological: it means working with others for common political aims. Given the multidimensionality of solidarity and various traditions of its understanding, it is useful to provide an analytical definition of solidarity practice. According to Sangiovanni (2015), solidarity differs from other types of collective action in regard to five aspects. Firstly, A acts in solidarity with B when A and $\mathrm{B}$ share the goal to overcome some significant adversity, although no joint agency of $\mathrm{A}$ and $\mathrm{B}$ is obligatory. Secondly, both ways of $A$ and $B$ to achieve the goal mesh. Thirdly, a commitment of $A$ and $B$ to the goal is needed which means that if $\mathrm{A}$ is involved in activity only for financial reasons, it may not be acknowledged as solidarity practice. This criterion, however, does not exclude pragmatic concerns of solidarity. Fourthly, A and B are disposed to incur significant costs to realize the goal. This assumes that A's action may not be meaningless to A to be recognized as a solidarity practice. And finally, features of action of $\mathrm{A}$ and $\mathrm{B}$ are not a common knowledge, which undertakes that $A$ and $B$ may act "in parallel" not knowing about each other; A's action is not conditioned upon what B does. Although Sangiovanni's definition is coined for the sake of welfare state analysis, it seems that so defined solidarity practice may be applied to various circumstances and may take a form of either robust solidarity (solidarity with a group) or expressional solidarity (solidarity toward a group). The first one is perceived as moving people toward a collective action, as it is based on multidirectional relationships and includes joint interest, 
identification with a group and disposition to empathy. It is close to a notion of social solidarity (Bang 2015). The latter is founded on unidirectional relationship and entails action toward distant others and resembles political solidarity which is rather connective than collectivist in its nature (Bang, ibid.). Taylor (2015) interprets this form of solidarity as coherent with Gould's (2007) account of transnational solidarity meaning "supportive relations we can come to develop with people at a distance" these relations being "aimed at supporting people in overcoming oppression" (Taylor 2015: 129).

Since solidarity as a practice needs to be understood and analyzed within a broader cultural, political and economic setting (Bartkowski 2014; Lahusen 2016), in this chapter we locate solidarity action within specific meso-level social feature of the society, namely, social capital. In the subsequent section of the chapter, we propose a method of how to measure it. In general, we understand it as a set of social networks (or more broadly: social structures) and norms which may result in solidarity action(s). Thus, our account of social capital follows classical approaches which point to the role of its structural and normative components (Coleman 1988; Grootaert and van Bastelaer 2002; Putnam 2002: 9). In theory, the structural component of social capital entails relations and individuals' memberships in formal and informal social networks. The normative element of social capital includes values, beliefs and attitudes of a person, such as generalized trust, openness, a custom to act with others in a reciprocal manner, moral obligation to help the people in need, and so on. Both components may mutually reinforce-for example, the more various social contacts one has, the more she or he can be trusting others, and consequently the more prone to solidarity action he/she can be (Grootaert and van Bastelaer 2002; Narayan and Cassidy 2001).

The reasons for employing social capital perspective in this chapter are, firstly, of theoretical manner and, secondly, related to scientific discourse about the communist heritage in Poland which is considered to be harmful for social capital.

The theoretical connection between social capital and solidarity has already been acknowledged in the scientific literature ${ }^{1}$ (Portes 1998; Putnam 2000). As Lahusen (2016: 5 ) emphasizes, the analysis of solidarity can benefit from studies on social capital, which converge on the conviction that social capital is a necessary "glue" of social cohesion and thus essential for understanding the conditions and structures of solidarity. More specifically, from social capital scholarship, two stances emerge 
which are relevant for research on solidarity. We label the first one as a thesis about the consequences of the level of social capital. According to this argument, the more dense and diverse the social networks of an individual are, as well as the more trusting a person is, the more prone he or she is to get involved in cooperative behavior (Coleman 1988) and-consequently-in solidarity action.

The second stance may be labeled as a thesis on the consequences of the type of social capital. It assumes that the type of structural and normative elements of social capital affects individual's propensity to engage in solidarity action. Two types of social capital are differentiated in this context. The so-called bonding or thick social capital is based on relatively homogenous relations with family and friends. It entails strong norms of mutual support and thus might be exclusive. It is claimed that, for example, closed self-help groups may be based on this type of social capital and due to the effects of this form of social capital is named by some authors an "inwardlooking" social capital. Extreme form of this asset is close to traditional familialism (Banfield 1967; Portes 1998). On the other hand, the so-called bridging social capital, based on horizontal, crosscutting social networks and values of openness and generalized trust, positively contributes to social cooperation and public good at a systemic level (Putnam et al. 1994; Granovetter 1973).

When explaining causal mechanism which constitutes relation between social capital and solidarity action, a more general framework of its role in shaping political participation may be referred to. Following van Stekelenburg and Klandermans (2013), three mechanisms arising from diverse components of social capital may be pointed to in this regard. Firstly, the structural element of social capital refers to whom people can reach in actions of political participation. For example, engaging time to support the rights of refugees living in the camp in one's country may result from personal networks to volunteers already engaged in helping this group. Secondly, the relational component of social capital refers to informational, physical and emotional incentives toward solidarity action. Thus, the bigger and more diverse one's personal network is, the more information one has about, for example, significant adversity that other people are experiencing, methods of action to engage in help, possibilities to pool resources for action. Finally, the cognitive element encompasses shared representations, interpretations, systems of meaning - it may lead to consciousness raising or shaping one's political beliefs. This aspect of social embeddedness contributes to individuals' beliefs about whose and which 
rights may primarily need support and what kind of broader societal goals need to be achieved thanks to solidarity action.

Combining mentioned mechanisms with the type of social capital suggests each of them, comprising specific structures and societal values, is a trigger of different forms of solidarity action. Thus, homogenous personal ties, including strong bonds to family members and friends, accompanied by norms of involvement in the issues of family and/or close community which constitute bonding social capital would rather result in solidarity with a group. On the contrary, a diversified social network, including one's connections to people of different class, origins, both with disabilities and able-bodied, which provide knowledge about various forms of significant adversity which other people may experience would have a different effect. These structures and values representing Putnamian ideal would rather bring about solidarity toward a group, including transnational solidarity.

Clearly, the sketched framework serves only as a theoretical reference point. Empirical studies speak for much more nuanced relations between social structure, values and solidarity practices. They include, for example, Segall's (2005) study challenging positive impact of political participation on solidarity or Bang's (2004) claim to revise Putnamian approach of political participation being anchored in political virtues, since in everyday lives of contemporary citizens, "lighter" version of political engagement in building and running various governance networks comes to the fore. However, as noted, social capital perspective seems specifically relevant to research of solidarity in the Polish context. Both societal and academic debate about systematic transformation of Poland after the fall of communism tends to emphasize the "social capital problem" in Poland (Giza et al. 2000). Namely, it has been argued that civic participation and generalized trust in Poland are very low although typical of post-communist country (see e.g. Guasti 2016; Jakubowska and Kaniasty 2014; Czapiński 2014). This stance has been recently challenged, though. Firstly, it is claimed that vibrant examples of social capital have been overlooked due to methodological Occidentalism of dominant civil society studies (Jacobsson and Korolczuk 2017; Tworzecki 2008). Secondly, it is emphasized that on the contrary to Putnamian model, church-related activism does not result in withdrawal from public engagement and depicts important form of political participation in Poland (Żukowski and Theiss 2009). Thirdly, recent massive protests against populist and conservative turn in Polish public policy after Law and Justice came into power in 2015 prove 
high potential of massive political mobilization in Poland (see Karolewski 2016).

Thus, we follow "bonding" and "bridging" social capital distinction in a somewhat provocative manner, rather referring to debate which emphasizes high level of familialism (bonding social capital) in Poland than assuming that mentioned dichotomy may be regarded as justified social sciences category. Against this backdrop, our focus is to differentiate between the structures and social norms which are labeled as "bonding" social capital and the structures, actions and values referred as to "bridging" social capital. Our research questions focus on the impact of these two phenomena on solidarity behaviors both in general and specifically at transnational level. As noted, in particular we aim at explaining the relation between structures and values inherent in different types of social capital and different scopes of solidarity action. Central to our investigation are the questions: which social networks and values contribute to solidarity actions in general? But foremost-which contribute to solidarity with people abroad? Building on the presented literature, we hypothesize that (1) bonding social capital (based on family and friendship ties) has a negative impact on solidarity with addressees of international scope and (2) bridging social capital (generalized trust and civic engagement) has positive impact on solidarity behaviors, in particular in regard to behaviors with international scope of addressees.

\section{Measuring Individual Transnational Solidarity: Methods AND DATA}

The sample used for our analysis consists of 2119 respondents from Poland, gathered in an international survey carried out within the framework of TransSOL project (for more details about the survey-see the Introduction to this book). The basic socio-demographic characteristics of this group are provided in Table 5.1. The sample is representative for all age groups. Each age group consists of over 200 respondents, which exceeds 10 percent of the total population. The largest group consists of respondents aged between 55 and 64 years old, and the smallest group consists of the youngest group of adults below 25 years old. The educational structure of the Polish population of adults (people 18 years old and older) is also closely reflected in our sample. It is presented with the account of a very detailed set of categories. These categories are similar to 
Table 5.1 Socio-demographic characteristics of Polish respondents in TransSOL survey

\begin{tabular}{lrr}
\hline & $\begin{array}{c}\text { Number of } \\
\text { respondents }\end{array}$ & $\begin{array}{c}\text { \% in the weighted } \\
\text { sample }\end{array}$ \\
\hline Gender & & \\
Female & 1107 & 47.7 \\
Male & 1012 & 52.3 \\
Age groups & & \\
18-24 & 221 & 10.4 \\
$25-34$ & 395 & 18.6 \\
$35-44$ & 402 & 19.0 \\
$45-54$ & 336 & 15.9 \\
$55-64$ & 514 & 24.2 \\
65 and older & 252 & 11.9 \\
Education & & \\
Primary education or less & 33 & 1.5 \\
Lower secondary education & 42 & 2.0 \\
Vocational upper secondary education & 432 & 20.4 \\
Post-secondary education with access to tertiary & 1048 & 49.5 \\
Post-secondary-non-tertiary & 172 & 8.1 \\
Short-cycle (3-4 years) tertiary education & 40 & 1.9 \\
Long-cycle (4+ years) tertiary education & 111 & 5.2 \\
Master's equivalent education & 232 & 11.0 \\
Doctoral or equivalent level & 9 & 0.4 \\
\hline
\end{tabular}

Notes: Frequencies and percentages are calculated with the use of variable: weight_country. This applies to all the tables in this chapter

the ISCED (International Standard Classification of Education) seven categories of education levels (UNESCO 1997).

According to the twofold goal of this chapter, its first section has a descriptive character and aims at presenting the frequency of three different types of solidarity behaviors/practices toward three groups of addressees in detail, that is, among groups identified on the base of the distributions of three basic socio-demographic variables such as gender, age and education. In order to present these frequencies, we use three responses for three questions from the TransSOL survey. All the questions were formulated similarly- "Have you ever done one of the following in order to support the rights of people/groups in ...?" -but ended up referring to three different groups of addressees of the support, that is, people/groups in respondent's own country, in other countries within the EU and in countries outside the EU. The responses which we conceptualize as three 
different types of solidarity behaviors/practices were (a) attended a march, protest or demonstration, (b) donated money and (c) donated time.

The second section of this chapter explores the role of these sociodemographic determinants, as well as the role of two types of social capital based on close family and friendship ties (bonding social capital) and on civic-associational ties (bridging social capital), on the propensity of Poles to engage in mentioned solidarity practices. As a generalized solidarity behavior, we label any form of the three researched solidarity activities (i.e. protest activity, time donation and money donation) to support the rights of people in any location (in respondent's country, other EU countries or in other countries outside the EU). In this section we also explore the impact of the same determinants for the propensity of solidaristic Poles (the subgroup that had engaged in any form of solidarity behavior) to engage specifically in transnational solidarity. As transnational solidarity, we understand the support either for people from other EU countries or (and) other countries outside EU. In order to achieve both aims, we estimate two separate logistic regression models. The first model uses the full sample of Polish respondents, and the second model is run on the subsample of Poles who engage in any form of solidarity behavior.

In order to operationalize the two types of social capital as explanatory variables, we use a series of questions included in TransSOL survey which we divide into two blocks, according to the type of social capital. In the group of indicators of "bonding social capital", we include four indicators. Firstly, contacts with friends - a quasi-continuous variable, based on the survey question: "During the past month, how often have you met socially with friends not living in your household?" The answers included four frequencies to choose from: less than once this month (1); once or twice this month (2); every week (3); almost every day (4). Secondly, contacts with family - a binary variable based on the survey question: "Please say if each of the following do or do not apply to you: I have seen a family member over the last six months (other than my parents or children)?" The answers included yes (1)/no (0) option only. Thirdly, formalized family ties - which was created on the base of marital status variable in the survey, from which we identified respondents who were married or in civil/legally registered union as being in a formalized relationship (1). And finally, receiving help in community-a quasi-continuous variable, based on the question: "In the past 12 months, how often did you get help such as getting a lift with someone, help in looking after children, having shopping done, having something repaired at your house etc.?" The answers 
included four frequencies to choose from: less than once this month (1); once or twice this month (2); every week (3); almost every day (4).

In the group of "bridging social capital", we included five variables: membership in civil society organization(s) (any type of membership ${ }^{2}$ in any organization from the list provided in the TransSOL survey ${ }^{3}$ ). Secondly, a generalized trust level - a quasi-continuous variable which was based on the survey question: "Generally speaking, would you say that most people can be trusted, or that you can't be too careful in dealing with people?" to which the answers included an 11-point scale where 0 indicated an attitude "You can't be too careful" and 10 "Most people can be trusted". Thirdly, political participation in the form of voting - a binary variable which was based on the question: "Did you vote in the national election October 25, 2015?" The answers included yes (1)/no (0) option only. Furthermore, we included-local attachment, which we understood as an aspect of local citizenship - a binary variable which was constructed on the base of the answers "very attached" to the question: "Please tell me how attached you fell to your country/city/town/village?" Finally we also added interest in politics - a binary variable which was created based on the survey question: "How interested, if at all, would you say you are in politics?" The answers included five options, from which we identified "very" and "quite" interested responses and coded them as " 1 ", and other answers, including don't know option, we coded as "0".

The Table 5.2 presents basic statistics for the main explanatory variables used in both models.

Table 5.2 Explanatory variables—frequencies, means and standard deviations

\begin{tabular}{|c|c|c|}
\hline Ordinal (binary) variables & Percent of values $=1$ & \\
\hline Formalized family ties & 59 & \\
\hline Contacts with family & 77.7 & \\
\hline Membership in organizations & 30.3 & \\
\hline Interest in politics & 72.8 & \\
\hline Political participation & 75.2 & \\
\hline Local attachment & 62.3 & \\
\hline Continuous variables & Mean & Standard deviation \\
\hline Contacts with friends & 2.33 & $(0.87)$ \\
\hline Receiving help in community & 1.51 & $(0.83)$ \\
\hline Generalized trust level & 3.76 & $(2.72)$ \\
\hline
\end{tabular}

Notes: Means for binary variables indicate the percentage of respondents with variable value equal to 1 


\section{Solidarity Behaviors in Poland: Three Types of Support for Different Groups of Addressees According to the Geopolitical Proximity}

The frequency of solidarity behaviors in Poland varies significantly between types of activity and between geopolitical scopes of addressees. As shown in Table 5.3, 16.3 percent of Polish respondents report they have ever taken part in a march, protest or demonstration in order to support the rights of people in Poland. ${ }^{4}$ A slight overrepresentation of men in protest activity, but nothing statistically significant can be seen. Although some studies on political participation in Western societies prove protest behavior to be only form of political participation in which women are more active than men (Burns et al. 2001: 246), our finding is consistent with previous research, for example, by Domański (2009: 227) who showed men are more likely to protest in Poland than women. Similarly to his study and the general pattern (e.g. Pattie et al. 2004: 85 ), the higher education level turned to coincide with more frequent experience of participation in protest activities, ranging from 12.2 percent among respondents who have completed vocational upper secondary education to 22.0 percent among those who have obtained a MA title. In regard to age groups, a U-shaped relationship is present: the youngest respondents (age 18-24 years), as well as the oldest (above 65 years) subpopulation, reveal the highest rates of protest participation. This may be explained by co-occurrence of two features: typical for the EU higher propensity of younger generations to involve in protests, mainly due to higher tolerance level of youth and a higher level of membership in trade unions among the older generations, which act as a mobilization force for the members (Domański 2009; Żuk and Żuk 2015). Moreover, since we have asked if respondent has ever taken part in protest activity, we can see a cumulative effect of political experiences among older generations.

The share of Poles who participate in protest activities to support the rights of people in other countries in the EU is only 6 percent (see Table 5.3), that is, by more than half smaller than the support for the compatriots. Gender, education and age composition of this group are similar to the group of those respondents who have stand for Poles' rights. 
Table 5.3 Participation in march, protest or demonstration in order to support the rights of people: in respondent's country, in other countries in the EU and in countries outside the EU

\begin{tabular}{|c|c|c|c|c|c|c|}
\hline & \multicolumn{2}{|c|}{ In the country } & \multicolumn{2}{|c|}{$\begin{array}{l}\text { Other countries } \\
\text { in } E U\end{array}$} & \multicolumn{2}{|c|}{$\begin{array}{c}\text { Other countries } \\
\text { outside EU }\end{array}$} \\
\hline & $n$ & $\%$ & $n$ & $\%$ & $n$ & $\%$ \\
\hline Total & 346 & 16.3 & 127 & 6 & 118 & 5.6 \\
\hline \multicolumn{7}{|l|}{ By gender } \\
\hline Men & 171 & 16.9 & 69 & 6.8 & 61 & 6 \\
\hline Women & 175 & 15.8 & 58 & 5.2 & 58 & 5.2 \\
\hline \multicolumn{7}{|l|}{ By education } \\
\hline Primary education or less & 0 & 0 & 0 & 0 & 2 & 6.9 \\
\hline Lower secondary education & 4 & 9.6 & 1 & 1.8 & 2 & 4.2 \\
\hline $\begin{array}{l}\text { Vocational upper secondary } \\
\text { education }\end{array}$ & 53 & 12.2 & 30 & 7 & 29 & 6.6 \\
\hline $\begin{array}{l}\text { Upper secondary with access } \\
\text { to tertiary }\end{array}$ & 180 & 17.2 & 55 & 5.3 & 47 & 4.5 \\
\hline Post-secondary education & 25 & 14.4 & 11 & 6.5 & 10 & 5.9 \\
\hline $\begin{array}{l}\text { Short-cycle ( } 3-4 \text { years }) \\
\text { tertiary education }\end{array}$ & 6 & 14.7 & 5 & 11.3 & 2 & 5.7 \\
\hline $\begin{array}{l}\text { Long-cycle ( } 4+\text { years) tertiary } \\
\text { education }\end{array}$ & 25 & 22.6 & 6 & 5.5 & 7 & 6.6 \\
\hline Master's equivalent education & 51 & 22 & 19 & 18.1 & 19 & 8 \\
\hline Doctoral or equivalent level & 2 & 24.1 & 0 & 0 & 1 & 8 \\
\hline \multicolumn{7}{|l|}{ By age groups } \\
\hline $18-24$ & 39 & 17.6 & 6 & 2.8 & 15 & 6.9 \\
\hline $25-34$ & 68 & 17.2 & 27 & 7 & 32 & 8.2 \\
\hline $35-44$ & 51 & 12.7 & 25 & 6.3 & 23 & 5.7 \\
\hline $45-54$ & 47 & 13.9 & 14 & 4.2 & 17 & 5.8 \\
\hline $55-64$ & 87 & 16.9 & 35 & 6.9 & 16 & 3.2 \\
\hline 65 and older & 54 & 21.5 & 19 & 7.6 & 15 & 5.8 \\
\hline
\end{tabular}

Notes: Frequencies and percent are waged according to the country wage

Qs: Have you ever done one of the following [item: attended a march, protest or demonstration] in order to support the rights of people/groups in your own country/in other countries within the EU/in other countries outside the EU?

A similar share (5.6 percent) of the Polish population has the experience of protesting with an aim to support the rights of people in other countries outside the EU. Although this share is only slightly lower than in the case of protests which are aimed to support other EU countries' citizens, it needs to be noticed that only a limited overlap of both groups of protestors 
Table 5.4 Donating time in order to support the rights of people in respondent's country, in other countries in the EU and in countries outside the EU

\begin{tabular}{|c|c|c|c|c|c|c|}
\hline & \multicolumn{2}{|c|}{ In the country } & \multicolumn{2}{|c|}{$\begin{array}{l}\text { Other countries } \\
\text { in } E U\end{array}$} & \multicolumn{2}{|c|}{$\begin{array}{c}\text { Other countries } \\
\text { outside EU }\end{array}$} \\
\hline & $n$ & $\%$ & $n$ & $\%$ & $n$ & $\%$ \\
\hline Total & 511 & 24.1 & 266 & 12.5 & 241 & 11.4 \\
\hline \multicolumn{7}{|l|}{ By gender } \\
\hline Men & 244 & 24.1 & 128 & 12.7 & 109 & 10.8 \\
\hline Women & 267 & 24.2 & 137 & 12.4 & 131 & 11.9 \\
\hline \multicolumn{7}{|l|}{ By education } \\
\hline Primary education or less & 6 & 17.1 & 1 & 3.6 & 1 & 3.6 \\
\hline Lower secondary education & 12 & 27.3 & 3 & 7.8 & 4 & 9.6 \\
\hline $\begin{array}{l}\text { Vocational upper secondary } \\
\text { education }\end{array}$ & 83 & 19.1 & 67 & 15.5 & 50 & 11.6 \\
\hline $\begin{array}{l}\text { Upper secondary with access to } \\
\text { tertiary }\end{array}$ & 241 & 23 & 112 & 10.7 & 110 & 10.5 \\
\hline Post-secondary education & 47 & 27.4 & 21 & 12.3 & 15 & 8.5 \\
\hline $\begin{array}{l}\text { Short-cycle ( } 3-4 \text { years) tertiary } \\
\text { education }\end{array}$ & 8 & 20 & 4 & 9.5 & 6 & 14.7 \\
\hline $\begin{array}{l}\text { Long-cycle ( } 4+\text { years) tertiary } \\
\text { education }\end{array}$ & 34 & 30.9 & 16 & 14.2 & 11 & 10 \\
\hline Master's equivalent education & 76 & 32.7 & 40 & 17.3 & 41 & 17.6 \\
\hline Doctoral or equivalent level & 5 & 55 & 2 & 16.4 & 3 & 31.2 \\
\hline \multicolumn{7}{|l|}{ By age groups } \\
\hline $18-24$ & 65 & 29.7 & 34 & 15.3 & 31 & 14.1 \\
\hline $25-34$ & 105 & 26.7 & 55 & 13.9 & 45 & 11.3 \\
\hline $35-44$ & 70 & 17.5 & 42 & 10.5 & 38 & 9.6 \\
\hline $45-54$ & 87 & 26 & 44 & 13.1 & 38 & 11.4 \\
\hline $55-64$ & 119 & 23.1 & 63 & 12.2 & 59 & 11.4 \\
\hline 65 and older & 64 & 25.5 & 28 & 11.1 & 29 & 11.7 \\
\hline
\end{tabular}

Qs: Have you ever done one of the following [item: donate time] in order to support the rights of people/ groups in your own country/in other countries within the EU/in other countries outside the EU?

has been observed. 36.2 percent of Polish citizens who have attended the protests supporting EU citizens have also protested for rights of non-EU citizens.

Not surprisingly donating time in order to support others' rights is a much more frequent solidarity action in Poland than protesting (see Table 5.4). As much as 24.1 percent of Polish society has devoted time to support the rights of some groups in the country. Given that other studies 
on activism in Poland reveal that 20 percent of respondents claim to engage in unpaid work for some societal goals in the previous year (CBOS 2016:10), it seems that a narrow understanding of supporting rights of compatriots was present in our sample. A similar pattern in regard to education and age may be observed among those who donated time for compatriots as among those who were engaged in protests. The propensity to donate time grows with educational level and follows a U-shaped relationship with age, as it was in case of protests.

Similarly to the mentioned protesting behavior, the share of Poles who donated their time to support others' rights falls with the geographical scope of the addressees. 12.5 percent of Polish respondents report to have been engaged in donating time to support the rights of people in other countries of the EU. The same activity aimed at supporting people outside the EU has been reported by 11.4 percent of Polish respondents. It may be hypothesized that the younger subgroups are slightly more likely to be engaged in this type of solidarity behavior, although, as noted, the small numbers of cases do not allow us for far-reaching interpretations. According to other surveys conducted in Poland, 27 percent of Poles devotes some time in the year to services to people outside the family or for organizations, and 15 percent claims to engage in voluntary work (Czapiński 2015: 345). We can see that only a relatively small share of these activities is solidarity in our understanding-that is, supports rights of others.

Consistent with international studies in the field (e.g. Marien et al. 2010: 196) which prove donating money to be one of the most frequent political participation forms, it turned out to be the most frequent solidarity behavior in our study. As presented in Table 5.5, 29.6 percent of Polish respondents reveal that they have donated money to support compatriots. Both higher education level and age improve the chances of being engaged in donating money. Financial support to the EU citizens living in other countries is, again, over twice less frequent; 13.2 percent of respondents have been active in this manner, whereas the educational and age composition of this group resembles similar to the previous one which might be explained by a significant overlap of these two groups. Over 61 percent of Poles who donate money to support other EU countries' inhabitants also financially support Polish citizens.

It should be noticed that on the contrary to protest activities devoting one's own time to support others, donating money to support people outside the EU is more widespread in Polish society than financial help to 
Table 5.5 Donating money in order to support the rights of people in respondent's country, in other countries in the EU and in countries outside the EU

\begin{tabular}{|c|c|c|c|c|c|c|}
\hline & \multicolumn{2}{|c|}{ In the country } & \multicolumn{2}{|c|}{$\begin{array}{l}\text { Other countries } \\
\text { in } E U\end{array}$} & \multicolumn{2}{|c|}{$\begin{array}{c}\text { Other countries } \\
\text { outside EU }\end{array}$} \\
\hline & $n$ & $\%$ & $n$ & $\%$ & $n$ & $\%$ \\
\hline Total & 627 & 29.6 & 280 & 13.2 & 381 & 18 \\
\hline \multicolumn{7}{|l|}{ By gender } \\
\hline Men & 283 & 28 & 133 & 13.1 & 188 & 18.6 \\
\hline Women & 345 & 31.1 & 147 & 13.2 & 193 & 17.4 \\
\hline \multicolumn{7}{|l|}{ By education } \\
\hline Primary education or less & 3 & 10.1 & 1 & 3.5 & 2 & 6.4 \\
\hline Lower secondary education & 10 & 24.3 & 4 & 9.7 & 7 & 16.9 \\
\hline $\begin{array}{l}\text { Vocational upper secondary } \\
\text { education }\end{array}$ & 109 & 25.2 & 53 & 12.2 & 75 & 17.3 \\
\hline $\begin{array}{l}\text { Upper secondary with access to } \\
\text { tertiary }\end{array}$ & 329 & 31.4 & 146 & 13.9 & 195 & 18.6 \\
\hline Post-secondary education & 51 & 29.9 & 23 & 13.2 & 27 & 15.9 \\
\hline $\begin{array}{l}\text { Short-cycle ( } 3-4 \text { years) tertiary } \\
\text { education }\end{array}$ & 13 & 32.7 & 8 & 19.2 & 8 & 20.6 \\
\hline $\begin{array}{l}\text { Long-cycle ( } 4+\text { years) tertiary } \\
\text { education }\end{array}$ & 28 & 25.1 & 12 & 11.1 & 20 & 18 \\
\hline Master's equivalent education & 79 & 34 & 31 & 13.5 & 43 & 18.5 \\
\hline Doctoral or equivalent level & 5 & 55.9 & 2 & 16.7 & 4 & 39.5 \\
\hline \multicolumn{7}{|l|}{ By age groups } \\
\hline $18-24$ & 39 & 17.5 & 15 & 6.8 & 30 & 13.7 \\
\hline $25-34$ & 103 & 26 & 34 & 8.5 & 43 & 11 \\
\hline $35-44$ & 100 & 24.8 & 44 & 10.8 & 56 & 13.9 \\
\hline $45-54$ & 111 & 33 & 56 & 16.5 & 67 & 20 \\
\hline $55-64$ & 187 & 36.5 & 95 & 18.4 & 120 & 23.4 \\
\hline 65 and older & 88 & 35.1 & 37 & 14.8 & 65 & 25.6 \\
\hline
\end{tabular}

Qs: Have you ever done one of the following [item: donate money] in order to support the rights of people/groups in your own country/in other countries within the EU/in other countries outside the EU?

EU inhabitants. Eighteen percent of the respondents claim they have donated money to support other people not living in the EU. Only 39.9 percent of them also financially support EU inhabitants. As in the case of other mentioned types of financial help, also in case of extra-EU financial support, higher education and age (with exception of people aged more than 65 years) coincide with more frequent solidarity behavior.

To sum up, out of the researched political acts of solidarity, the most frequent is donating money to support the rights of other people. Secondly, 
engaging one's own time is practiced. If our respondent is seen by us as being solidarity with some geographical group, it most probably means she or he donates money and/or time to support others' rights. It is much less likely that he or she has participated in the protests with a similar goal. It should be noticed that in the case of some researched activities, we have observed particular patterns of engagement across subpopulations. In regard to gender, we see men are involved in protests and money donation, whereas women are rather engaging their own time (e.g. as volunteers). With regard to age groups, transnational solidarity in the form of protesting is more frequent in the group of people aged 25-34, whereas the older generation (55-64 years) rather donates money. Educational attainment, as in any time of political activity, is positively correlated with engagement in all three solidarity practices.

Table 5.6 shows the frequency of generalized solidarity behaviors (i.e. any form from the three analyzed solidarity practices) toward different combinations of addressees. Almost 40 percent of Polish respondents declared having no experience of participation in solidarity practices, no matter the geopolitical scope of the addressees. The remaining 60.3 percent of respondents-which, as specified earlier, undertake generalized solidarity practices (solidaristic respondents) — can be divided into two groups. The first group (21.3 percent of all respondents, i.e. 35.3 percent of the "solidaristic respondents") includes respondents who were solidaristic in supporting the rights of compatriots only. The second group (39 percent of all respondents, i.e. 64.7 percent of the "solidaristic respondents") participated (also) in solidarity action in order to support the rights of people in other countries. Table 5.6 provides information on the

Table 5.6 Solidarity practices in Poland with different scopes of beneficiaries

\begin{tabular}{lrl}
\hline & Frequency & $\begin{array}{c}\text { \% of all } \\
\text { respondents }\end{array}$ \\
\hline No solidarity practice at any level & 842 & 39.7 \\
Solidarity practices, including & 1277 & 60.3 \\
Solidarity action(s) only at the country level & 450 & 21.3 \\
Solidarity actions at the country and EU level & 147 & 6.9 \\
Solidarity actions at the country and outside EU level & 185 & 8.7 \\
Solidarity actions at all levels & 292 & 13.8 \\
Solidarity action(s) only at the supranational level & 63 & 3 \\
(EU or outside EU) & & \\
\hline
\end{tabular}

Notes: Frequencies and percent are waged according to the country wage 
more detailed subgroups. For example, almost 14 percent of all respondents reported being engaged in at least one supportive practice at all geopolitical levels.

The findings on differences in geographical scope of solidarity action are consistent with earlier study of Bartkowski (2014) who argues that after economic crisis of 2008, solidarity attitudes toward neighbors and compatriots have grown and that, however, readiness to help people living abroad and in particular outside the EU has fallen, widening the gap between in-group and out-group solidarity. The mentioned study, however, refers to attitudes, whereas our investigation is focused on factual solidarity behaviors. Although only 2.4 percent of Poles declare "they are concerned about the Europeans to a very high extent" and 12.4 confirm "they are concerned to some extent" (years 2005-2009 data based on EVS and WVS surveys), our research shows that 36 percent of Poles has participated in some activity to support the rights of people living in the EU. As further discussed in the last section of this chapter, we may hypothesize that even for some respondents who are not necessarily concerned about the EU as a polity and its members, there are other incentives to support specific rights of citizens living in other EU countries.

\section{Bonding and Bridging Social Capital and Their Impact on (Transnational) Solidarity Behavior}

Table 5.7 presents the results of the estimated logistic regressions. As expected, we find diverging results for both models, the one for propensity to engage in solidarity practices among general population and the other for propensity to engage particularly in transnational solidarity among the subgroup of "solidaristic" Poles. On the one hand, we find that such bridging capital indicators as membership in organizations and generalized trust level positively impact both the propensity to engage in solidarity practices in general and toward transnational solidarity action among the "solidaristic" Poles. Polish respondents who declared to be members of at least one civic organization had over four times higher propensity to engage in any solidarity practice than Poles not being members of any organization. Furthermore, solidaristic Poles, who declared to be members of civic organization(s), had again almost two times higher propensity to engage in transnational solidarity practices than the rest of the "solidaristic" Poles. 
Table 5.7 Logistic regression results $(\exp \beta)$ for the model of general solidarity and model of transnational solidarity

\begin{tabular}{|c|c|c|}
\hline & General solidarity & Transnational solidarity \\
\hline & Model 1 & Model 2 \\
\hline \multicolumn{3}{|l|}{ Socio-demographic factors } \\
\hline Gender (ref. male) & 1.09 & 1.02 \\
\hline Age & 1 & $1.01 * *$ \\
\hline Education & $1.06^{*}$ & 1.03 \\
\hline Income & 1.02 & 0.94 * * \\
\hline \multicolumn{3}{|l|}{ Bonding social capital } \\
\hline Formalized family ties (1) & 0.95 & 1.12 \\
\hline Contacts with family & 1.09 & 1.08 \\
\hline Contacts with friends & $1.19 * * *$ & 0.96 \\
\hline Receiving help in community & 0.98 & 1.52 \\
\hline \multicolumn{3}{|l|}{ Bridging social capital } \\
\hline Membership in organizations (1) & $4.57 * * *$ & $1.97 * * *$ \\
\hline Generalized trust level & $1.04 *$ & $1.06 * *$ \\
\hline Voting (1) & $1.55^{* * *}$ & 0.96 \\
\hline Local attachment $(1)$ & 1.07 & $0.79 *$ \\
\hline Interest in politics (1) & $1.59 * * *$ & 0.88 \\
\hline Constant & $0.17 * * *$ & 0.95 \\
\hline$N$ & 1818 & 1138 \\
\hline
\end{tabular}

Notes: The level of significance are described by number of stars: ${ }^{* *} p \leq 0.01,{ }^{* *} p \leq 0.05,{ }^{*} p \leq 0.1$

On the other hand, we find that local attachment (to the country or to the city/town of the respondent) proves to be negatively correlated only with transnational type of solidarity practice. The impact of local attachment on solidarity behavior in general is positive, although in our analysis this relationship does not prove to be statistically significant. Furthermore, we find that electoral participation as well as interest in politics positively and significantly impact involvement in solidarity practices in general.

People who declared they are quite or very interested in politics have, on average, nearly 60 percent higher propensity to declare being involved in any form of solidarity behavior. People who declared that they participated in the last parliamentary elections in Poland (in 2015) were 55 percent more likely to be involved in such activity. These aspects of bridging social capital do not prove to have significant impact on propensity to engage in transnational solidarity practices among "solidaristic" Poles. 
Most of the indicators of bonding social capital did not prove to have significant impact on solidarity behaviors. However, the frequency in contact with friends proved to be positively related to the engagement in solidarity behaviors in general. Its impact on the propensity of "solidaristic" Poles to engage in transnational solidarity practices was found to be negative, although this effect was not statistically significant in our model.

Both models also point at the insignificant role of gender in solidarity behaviors. Men are as likely as women to undertake solidarity actions and among these participate in actions with a transnational scope. The positive impact of age was found to be statistically significant only in model for transnational solidarity and positive education only for model for general solidarity (although the differences in the impact between both models were very small). Finally, income showed significant and negative impact only for transnational solidarity practices among "solidaristic" Poles.

\section{INDIVIDUAL TransNational SOLIDARITY: Beyond Bridging-Bonding Divide? Discussion AND CONCLUSION}

Our findings provide evidence that partially supports our hypotheses on the relationships between social capital and solidarity practices outlined in the theoretical section. Firstly, we have observed that such element of bonding social capital, as frequent contacts with friends, positively affects general solidarity. Following van Stekelenburg and Klandermans (2013), we may interpret that the structural, relational and cognitive elements of social capital-based on contacts with friends - enhance individuals' propensity to take action aimed at supporting someone's rights. Thus, radical assumptions about the role of family ties (Putnam et al. 1994) and their impact on solidarity have not been confirmed in our study. We have not observed any negative impact of strong family bonds on involvement in solidarity action.

Secondly, a strong, positive impact of bridging social capital on solidarity practices, both in general and in regard to people living abroad, has been confirmed. Such aspects of social capital increase likelihood of engagement in any solidarity action, as membership in civil society organization, high level of generalized trust and attitudes of engagement in public issues which manifest in declared interest in politics and participation in elections. Membership in civil society organizations and trusting unknown others turn out to positively affect transnational solidarity action, too. 
Thus, our analysis confirms that both types of solidarity practices result from social embeddedness of a person. However, we can clearly see that the linkages between two types of social capital and two types of solidarity practices are nuanced and that specific pattern of causal relation emerges. Namely, it seems that classic Putnamian (Putnam et al. 1994) ideal of social capital is at least partly a bedrock for generalized solidarity practice, which according to our conceptualization encompasses also robust solidarity (solidarity in a group). Moreover, apart from such social norms as interest in politics and voting, it is also high education level which contributes to this type of solidarity. All these triggers taken together, it can be seen that general solidarity action in Poland stems from a relatively "elitist" social resources. This is consistent with previous studies on civil activism in Poland which was described as dispersed and confined within societal structures hardly accessible for broader citizenry (Kościański 2016: 236). However, transnational solidarity practice turned out to be embedded in different types of social capital. Surprisingly, these are relatively older and less affluent Poles who are not interested in politics, but trusting others and strongly attached to locality, who are more likely to get involved in transnational solidarity action.

Relating our findings to the above-mentioned discussion about the unfavorable communist legacy of Polish civic practices (Guasti 2016; Jakubowska and Kaniasty 2014; Czapiński 2014), even if we assume that familialism and low interest in public sphere are a part of this heritage, it turns out to be a less dismantling transnational solidarity action than one may thought. As noted-spending time with family does not have a negative effect on solidarity action, whereas spending time with friends has only a positive effect. Moreover, we can see that transnational solidarity cannot be explained in terms of low interest in public issues or scarcity of financial assets and thus may be hardly seen as a result of civic virtues being destroyed by communism. It rather seems that a specific pattern based on combination of high trust, refraining from politics and glocal perspective on others' rights comes into the fore.

Thus, we may hypothesize that this type of civic activism is relatively immune to contemporary political narratives of Poland which suggest the need protect itself from "foreign values". Paradoxically, a tradition of acting out of the state's structures or even against them, practised during communist time in Poland, may be the heritage which some "transnationally solidaristic" Poles may refer to. This mechanism is supported by recent studies which prove that contemporary anti-Law and Justice demonstra- 
tions (Karolewski 2016) and transnational solidarity action of civil society organizations (Chimiak 2016) follow tradition of "Solidarity" values and its civil resistance action. Hence, in times when solidarity might be endangered "from above", the heritage of civic action form communist time may be a source to refer to when getting involved in solidarity action "from below".

\section{APPENDIX}

Variables in the models

Continuous variables

Age

Education

Income

Contacts with friends

Receiving help in community

Generalized trust level

Ordinal variables

Gender (ref. male)

Formalized family ties

Contacts with family

Interest in politics

Keeping informed about public

issues

Voting

Local attachment
Recoding from original variables

age - no recoding needed

education-no recoding needed

income - no recoding needed $(999=$ missing

values)

metfriends-no recoding needed

belp-no recoding needed

socialtrust_999 = 5; else was copied

gender - no recoding needed

mamarsts -3 and 6 recoded as 1 ; else $=0$

deprivepices_8-no recoding needed

polint -3 and 4 recoded to 1 ; else $=0$

news_12-no recoding needed

votenat_PL-3 recorded as 1 ; else $=0$

attachcountry_city 4 recoded as 1 ; else 0

\section{Notes}

1. It needs to be noticed that in significant part of relevant literature, the relation between social capital and solidarity is conceptualized in a different way than in this chapter. Solidarity is commonly understood only as specific attitude which leads to cooperation (social capital) (Portes 1998). This is also a result of frequent conceptualization of solidarity as a moral value and not a practice.

2. Active (belong and volunteer/unpaid work for) or passive (belong to only).

3. The list included such organizations as political party, trade union, labor union, human/development rights organization, civil rights/liberties organization, environment/anti-nuclear organization, peace/anti-war organization, occupy/anti-austerity organization, anti-capitalist, anti-globalization 
organization, anti-racist/migrant rights organization, disability rights organization, unemployment organization and refugees or asylum seekers organization.

4. According to 2014 ESS data, the percentage of people who report they have taken part in lawful public demonstration equals 2.8 in Poland. The response to TransSOL survey question-There are different ways of trying to improve things or help prevent things from going wrong. When have you LAST done the following?-Attended a demonstration, march or rally (item: 12 months)equals 11.7 percent. Due to a generally low level of participation in demonstrations in Poland (Domański 2009), we have decided to include in the analysis a question on long-term individual protest experiences.

\section{REFERENCES}

Banfield, E. (1967). The Moral Basis Of a Backward Society. New York: Free Press. Bang, B. H. P. (2004). Everyday Makers and Expert Citizens: Building Political not Social Capital. Working Paper, 1-32.

Bang, H. P. (2015). Between Democracy and Governance. British Politics, 10(3), 286-307.

Bartkowski, J. (2014). Solidarność społeczna i kryzys. Zmiany wartości w Europie i w Polsce w warunkach kryzysu. Acta Universitatis Lodzienis Folia Sociologica, 48(2014), 19-34.

Burns, N., Schlozman, K. L., \& Verba, S. (2001). The Private Roots of Public Action: Gender, Equality, and Political Participation. Cambridge: Harvard University Press.

CBOS. (2016). Potencjał społecznikowski oraz zaangażowanie w pracę społeczną. Komunikat z badań, 15/2016.

Chimiak, G. (2016). From Solidarność to Global Solidarity? The Engagement of Polish Civil Society in Development Cooperation. Studia Socjologiczne, 3(222), 165-198.

Coleman, J. (1988). Social Capital in the Creation of Human Capital. American Journal of Sociology, 94, S95-S120.

Czapiński, J. (2006). Polska-państwo bez społeczeństwa. Nauka, 1/2006, 7-26.

Czapiński, J. (2014). Kapitał społeczny. Diagnoza Społeczna 2013, Warunki i Jakość Życia Polaków - Raport, 320-334.

Czapiński, J. (2015). Stan społeczeństwa obywatelskiego. Diagnoza Społeczna 2015, Warunki i Jakość Życia Polaków - Raport. Contemporary Economics, $9 / 4,332-372$.

Domański, H. (2009). Społeczeństwa europejskie. Stratyfikacja i systemy wartósci. Warszawa: Scholar.

Giza, A., Marody, M., \& Rychard, A. (2000). Strategie i system. Polacy w obliczu zmiany spotecznej. Warszawa: IFiS PAN.

Gliński, P. (2006). Style dziatań organizacji pozarzadowych w Polsce. Grupy interesu czy pożytku publicznego? Warszawa: IFiS PAN. 
Gould, C. (2007). Transnational Solidarities. Journal of Social Philosophy, 38, $148-164$.

Granovetter, M. S. (1973). The Strength of Weak Ties. American Journal of Sociology, 78(6), 1360-1380.

Grootaert, C., \& Van Bastelaer, T. (Eds.). (2002). Understanding and Measuring Social Capital: A Multidisciplinary Tool for Practitioners (Vol. 1). World Bank Publications.

Guasti, P. (2016). Development of Citizen Participation in Central and Eastern Europe After the EU Enlargement and Economic Crises. Communist and PostCommunist Studies, 49(3), 219-231.

Jacobsson, K., \& Korolczuk, E. (2017). Civil Society Revisited. Lessons from Poland. New York: Berghahn Books.

Jakubowska, U., \& Kaniasty, K. (2014). Post-Communist Transformation in Progress: Poles' Attitudes Toward Democracy. Communist and Post-Communist Studies, 47(3-4), 399-407.

Karolewski, I. P. (2016). Protest and Participation in Post-Transformation Poland: The Case of the Committee for the Defense of Democracy (KOD). Communist and Post-Communist Studies, 49(3), 255-267.

Kolers, A. H. (2012). Dynamics of Solidarity. Journal of Political Philosophy, 20(4), $365-383$.

Kościański, A. (2016). Partycypacja obywatelska a syndrom zmiany orientacji życiowych w społeczeństwie polskim. In Przemiany kulturowe we wspótczesnej Polsce. IFIS PAN.

Krzemiński, I. (2010). Wielka Transformacja. Zmiany Ustroju w Polsce po 1989. Oficyna Łośgraf.

Lahusen, C. (2016). Transnational Solidarity within the European Union: Towards a Framework of Analysis. Paper presented at the 8th Pan-European Conference on the European Union. "The Union's Institutional and Constitutional Transformations: Stress or Adaptation?”, Trento, 15-18 June 2016.

Marien, S., Hooghe, M., \& Quintelier, E. (2010). Inequalities in NonInstitutionalised Forms of Political Participation: A Multi-Level Analysis of 25 Countries. Political Studies, 58(1), 187-213.

Narayan, D., \& Cassidy, M. (2001). A Dimensional Approach to Measuring Social Capital: Development and Validation of a Social Capital Inventory. Current Sociology, 49, 59-102.

Ost, D. (2006). The Defeat of Solidarity: Anger and Politics in Postcommunist Europe. Cornell University Press.

Pattie, C., Seyd, P., \& Whiteley, P. (2004). Citizenship in Britain: Values, Participation and Democracy. Cambridge: Cambridge University Press.

Portes, A. (1998). Social Capital: Its Origins and Applications in Modern Sociology. Annual Review of Sociology, 24(1), 1-24.

Putnam, R. D. (2000). Bowling Alone: The Collapse and Revival of American Community. New York: Simon \& Schuster. 
Putnam, R. (2002). Democracies in Flux. The Evolution of Social Capital in Contemporary Society. New York: Oxford University Press.

Putnam, R., Leonardi, R. \& Nanetti, R. (1994). Making Democracy Work: Civic Traditions in Modern Italy. Princeton University Press.

Sangiovanni, A. (2015). Solidarity as Joint Action. Journal of Applied Philosophy, $32(4), 340-359$.

Segall, S. (2005). Political Participation as an Engine of Social Solidarity: A Skeptical View. Political Studies, 53, 362-378.

Staniszkis, J. (2010). Samoograniczająca się rewolucja. Gdańsk: Europejskie Centrum Solidarności.

van Stekelenburg, J., \& Klandermans, B. (2013). The Social Psychology of Protest. Current Sociology, 61(5-6), 886-905.

Szymczak, W. (2008). Zaufanie społeczne i kondycja społeczeństwa obywatelskiego w Polsce. In A. Kościański \& W. Misztal (Eds.), Spoteczeństwo obywatelskie między idea a praktyka. Warszawa: IFIS PAN.

Taylor, A. E. (2015). Solidarity: Obligations and Expressions. Journal of Political Philosophy, 23(2), 128-145.

Tworzecki, H. (2008). A Disaffected New Democracy? Identities, Institutions and Civic Engagement in Post-Communist Poland. Communist and PostCommunist Studies, 41(1), 47-62.

UNESCO. (1997). International Standard Classification of Education-ISCED 1997: November 1997. UNESCO.

Żuk, P., \& Żuk, P. (2015). O kulturze protest jako rdzenin tradycji europejskiej. Warszawa: IW Książka i Prasa.

Żukowski, T., \& Theiss, M. (2009). Islands of Civic Engagement. Differences in the Level of Civic-Associational Social Capital. International Journal of Sociology, 39(4), 65-87.

Open Access This chapter is licensed under the terms of the Creative Commons Attribution 4.0 International License (http://creativecommons.org/licenses/ by $/ 4.0 /$ ), which permits use, sharing, adaptation, distribution and reproduction in any medium or format, as long as you give appropriate credit to the original author(s) and the source, provide a link to the Creative Commons license and indicate if changes were made.

The images or other third party material in this chapter are included in the chapter's Creative Commons license, unless indicated otherwise in a credit line to the material. If material is not included in the chapter's Creative Commons license and your intended use is not permitted by statutory regulation or exceeds the permitted use, you will need to obtain permission directly from the copyright holder.

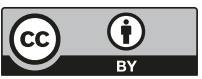

